\title{
SMEs: \\ How to Make a Successful Transition From Conventional Training Towards E-Learning
}

\author{
doi:10.3991/ijac.v3i2.1322 \\ Andrée Roy \\ Université de Moncton, Moncton, NB, Canada
}

\begin{abstract}
The purpose of this study is to define what eLearning consists of, its characteristics and the various barriers to it for SMEs and to verify, through a multiple case study, the extent to which Atlantic Canadian SMEs face the same barriers than larger organizations when they want to use e-Learning. The purpose of the study is also to present the different approaches, such as determine an overall learning strategy, develop a culture more conducive to eLearning and upgrade the technological skills of the employees, that small and medium-sized businesses can use if they want to make a successful transition from traditional training to e-Learning to train their employees.
\end{abstract}

Index Terms - barriers, e-Learning, SMEs, training, transition strategies toward e-Learning.

\section{INTRODUCTION}

Globalization, existing and emerging technological and organizational innovations, along with financial constraints and the tendency to reduce human resources, encourage a revision and even a major transition of organizations towards the use of technologies regarding the training aspect. The e-Learning, due to its numerous advantages, is gaining in popularity in recent years and is poised to replace training provided in class by an instructor. So, training provided in class by an instructor, which is called conventional training, is being replaced more and more by e-Learning in large businesses. Furthermore, the links between training, competitiveness and economic development intensify. To this end, Ref. [1] considers that in the knowledge-based economies, the investments of a company in training and the update of skills are one of the key elements of growth. According to this organization, small and medium-sized businesses (SMEs) need to exploit e-Learning to address their training needs and this in order to ensure their growth and survival. However, SMEs remain reluctant about the use of e-Learning. For what reasons? Is it because barriers in the adoption of e-Learning are insurmountable for them or because they do not know where to begin?

In Atlantic Canada, SMEs, which are defined as businesses having less than 500 employees, represent the majority of businesses and they also create the majority of jobs [2]. Due to their great flexibility and adaptability, they represent the sector of the economy that has the greatest growth rate and that creates the most employment $[3 ; 4]$. They are considered as the foundation of economic development [3; 5]. Therefore, it is important to know if the barriers that SMEs encounter when they want to use e-Learning are insurmountable or if they just do not know where to begin.

The purpose of this study is two-fold. After having identified what is e-Learning, based on a survey of the documentation on the issue, the first objective is to determine, through a case study, the barriers encountered by SMEs in Atlantic Canada in order to use e-Learning. The second step is to present the different approaches that small and medium-sized businesses can use if they want to make a successful transition from traditional training to e-Learning to train their employees.

\section{THEORETICAL CONTEXT}

Although the adoption of e-Learning technology for purposes of workplace training and human resource development is rapidly growing in large organisations, both private and public, and to a lesser extent in SMEs [6; 7], the practitioner literature shows different definitions of eLearning and that there are barriers in using e-Learning for enterprises and more particularly for SMEs.

\section{A. Definition of e-Learning in the workplace}

In the absence of a clear and common definition of eLearning, along with the presence of related terminology such as "computer-based training" and "distance learning”, conceptual ambiguity and problems of comparability can be encountered when this concept is used for research on workplace training [8; 9]. The definitions most often provided link learning activities and technologies. In this line of thought, Ref. [10] defines e-Learning as basically using the Internet, intranet, extranet, or other Web technologies to provide training to individuals in a synchronous or asynchronous mode, while for Ref. [11], it is defined as "the use of computer network technology, primarily over or through the Internet, to deliver information and instruction to individuals". A report by the American Commission on Technology and Adult Learning [12] states that "e-Learning is instructional content or learning experiences delivered or enabled by electronic technology". The Conference Board of Canada's [13] workplace e-Learning report provides that "e-Learning uses information and communication technologies (ICTs) to deliver content (learning, knowledge and skills) on a one-way (asynchronous) or two-way (synchronous) basis". Ref. [14] defines e-Learning as "the ability to deliver training and education via Web technology”. It is meant to improve training by providing current content anytime, anywhere, and offering learners a customized, interactive, 
just-in-time experience. For Ref. [15], e-Learning comprises all training activities that use Web technologies.

E-learning typologies that combine certain characteristics or criteria have also been developed by some authors [9]. Those characteristics most often used are: time, place, access and support, technology (development and delivery), interaction, personalisation and control [10; 16; 17].

\section{B. Barriers to e-Learning in SMEs}

Barriers to e-Learning as a method of training for learners, both for businesses and educational institutions, have been identified by various studies. For example, Ref. [18], mentions that the main barriers to the use of eLearning in Canada are learners and technical infrastructure. Among other barriers mentioned by Ref. [18], we find the lack of knowledge towards e-Learning, the accessibility, the lack of commitment from senior management, the lack of quality courses, the development costs and the priorities of investment. According to Ref. [19], the bandwidth, the access to the Internet, the reluctance of the employees to use the technologies, the lack of investment on the part of companies in technology and the lack of university-level courses and non-academic relevant to the needs of businesses are still barriers to eLearning. In addition to the lack of relevant courses, the reluctance of employees and the lack of expertise or technical capacity of these as barriers to e-Learning, Ref. [20] refers to the lack of realism of businesses towards what eLearning can and cannot do. The barriers facing companies when they want to use e-Learning are summarized in Table 1.

\section{RESEARCH METHODS}

Given the present state of knowledge on e-Learning in SMEs, the method used for this article includes a census of the literature on e-Learning combined with a qualitative and exploratory research approach, i.e. multiple case studies. The literature census covers more specifically what e-Learning consists of and its barriers. The case study method is well adapted in situations where theoretical propositions are few and field experience is still limited [39]. A multiple-site case study allows one to understand the particular context and evolution of each firm with regard to e-Learning. Sixteen SMEs located in the Atlantic region of Canada were studied, that is, four in each of the provinces of New Brunswick, Nova Scotia, Prince Edward Island and Newfoundland, selected to be sufficiently successful (at least 10 years in business) and representative in terms of industry and size, for theoretical generalization purposes. These manufacturing SMEs stem from various sectors, such as: textile, oil and gas, pulp and paper and processed food sector. Following North American research [5; 40], a small enterprise (SE) is defined as having 20 to 99 employees, whereas a medium-sized enterprise (ME) has 100 to 499.

Data were collected through semi-structured taperecorded interviews, ranging approximately two hours each, with the owner-manager or CEO and with the firm's HR manager or manager responsible for training. e-Learning users were also interviewed in four cases. Interview transcripts were then coded and analyzed following Ref. [41] prescriptions with the assistance of the Atlas.ti application.
TABLE I.

BARRIERS TO THE USE OF E-LEARNING

\begin{tabular}{|c|c|}
\hline Barriers & Explanation of barriers \\
\hline Accessibility & $\begin{array}{l}\text { Difficulty for the trainer and learner to acquire or } \\
\text { have access to the necessary technology (hardware, } \\
\text { software, bandwidth) [18;19;21;22;23;24;25; } \\
26 ; 27] \text {. }\end{array}$ \\
\hline $\begin{array}{l}\text { Training and } \\
\text { support not } \\
\text { available }\end{array}$ & $\begin{array}{l}\text { Teachers and learners do not always understand } \\
\text { how to use the technology required for the course } \\
\text { (computers, software, Internet, TV...) [19; 25; 27; } \\
28 ; 29 ; 30] \text {. } \\
\text { Support service not available or inadequate for } \\
\text { teachers and learners [25; } 29 ; 30] \text {. } \\
\text { Lack of support from senior administration [19; } \\
\text { 25]. } \\
\text { Lack of involvement of different stakeholders and } \\
\text { no strategic plan [25; } 31] \text {. }\end{array}$ \\
\hline $\begin{array}{l}\text { Cour } \\
\text { cour }\end{array}$ & $\begin{array}{l}\text { Determine the purpose of the course: learning } \\
\text { through technology or learn technology [32]. } \\
\text { Determine the course content and the order of } \\
\text { presentation of content [33; } 34] \text {. } \\
\text { Align the objectives of the course with the course } \\
\text { content and assessments [23; } 29] \text {. } \\
\text { Choose the method of training (an active method, } \\
\text { which allows the learner to construct their learning, } \\
\text { and have access to a teacher if necessary, is a better } \\
\text { method than an affirmative one) [28; 30]. } \\
\text { Determine the duration and cost [23; 29; 35]. } \\
\text { Lack of university-level courses and non-academic } \\
\text { relevant to businesses [19]. }\end{array}$ \\
\hline Interaction & $\begin{array}{l}\text { Lack of human interaction (face to face) [22; } 24 \text {; } \\
31] \text {. }\end{array}$ \\
\hline Learners & $\begin{array}{l}\text { The profile of the learner may not always match the } \\
\text { desired profile. The following characteristics are } \\
\text { desirable in order to ensure the success of the } \\
\text { training: self-motivated [18; 28; 29; 33; 36], ability } \\
\text { to work alone [28; 36], self-disciplined [18; 33; 36], } \\
\text { "focused" [18; 33]. }\end{array}$ \\
\hline Environment & $\begin{array}{l}\text { The political, social and economic forces which } \\
\text { may influence the choice of courses offered, the } \\
\text { quality of courses and the place [31]. }\end{array}$ \\
\hline Costs & $\begin{array}{l}\text { Costs (infrastructure, development and / or pur- } \\
\text { chase of course) required to support e-Learning [37, } \\
38] \text {. }\end{array}$ \\
\hline
\end{tabular}

For reasons of confidentiality, fictitious names of individuals and firms participating in the study were used. As presented in the research results section, these firms range in size from 60 to 485 employees and operate in industries whose technological intensity varies from low to high. All export except for one firm (M). The SMEs were regrouped in four e-Learning profiles of increasing intensity, based on the extent of their awareness and use of eLearning (none, weak, average, strong).

\section{RESEARCH RESULTS}

The majority of SMEs who participated in the study are quite aware of e-Learning and offer definitions that closely resemble those that are found in the literature. As indicated in Table 2, while the e-Learning concept is fairly well known by the majority of SMEs studied, it remains to be defined for some.

A detailed study of SMEs stated knowledge about eLearning and their use of it enables us to qualify their level of use. This analysis also provides for categorizing SMEs into four distinct profiles of e-Learning users. There are SMEs that use e-Learning a great deal (strong use), those that use it quite a bit (average use), those that 
TABLE II. ILLUSTRATIONS OF E-LEARNING’S DEFINITIONS OFFERED BY SMES

"It is any kind of system that allows you to learn a skill through the computer and basically, Internet, an interactive software or text notes; text notes would be the worst case scenario and some kind of interactive software that would give you results and test questions and so on....pick and choose kind of thing, so you can actually see if you are taking the right decisions. " Bert (B:491-496)

"E-Learning is learning trough a computer program, with a computer program on-line. It is almost like distance education whether it is local or not but it is obviously something you can do on a computer system as opposed to going to a building. " Fiona (F:437-438:442445)

"I am not familiar with the proper term but I suppose it is e for electronic. “ Gilbert (G:132-133)

TABLE III.

PROFILES OF E-LEARNING'S UTILIZATION BY SMEs ${ }^{1}$

\begin{tabular}{|c|c|c|c|c|}
\hline & $\begin{array}{c}\text { PROFLE I } \\
\text { STRONG } \\
(\mathrm{C}, \mathrm{D}, \mathrm{K}, \mathrm{L})\end{array}$ & $\begin{array}{c}\text { PROFLE II } \\
\text { AVERAGE } \\
(\mathrm{B}, \mathrm{E}, \mathrm{M}, \mathrm{O})\end{array}$ & $\begin{array}{c}\text { PROFILE III } \\
\text { WEAK } \\
(\mathrm{A}, \mathrm{F}, \mathrm{I}, \mathrm{J})\end{array}$ & $\begin{array}{c}\text { PROFLLE IV } \\
\text { NoN-EXISTENT } \\
\text { (G, H, N, P) }\end{array}$ \\
\hline $\begin{array}{c}\text { SIZE } \\
\text { NUMBERS OF } \\
\text { EMPLOYEES }\end{array}$ & 300 TO 485 & 60 TO 280 & 150 TO 350 & 75 TO 400 \\
\hline $\begin{array}{c}\text { E-LEARNING } \\
\text { UTLLIZATION }\end{array}$ & STRONG & AVERAGE & WEAK & NON-EXISTENT \\
\hline
\end{tabular}

don't use it much (weak use), and those that don't use it at all (non-existent use) as indicated in Table 3.

SMEs encounter some barriers when they want to use eLearning as a means of training. Even SMEs who rarely or never use e-Learning are aware that certain barriers may be encountered with e-Learning.

\section{A. Perceived barriers of e-Learning by SMEs}

The barrier which is most often quoted, in fact it is mentioned by all SMEs interviewed, is the one connected with the bandwidth, which is part of the accessibility. The capacity to download e-Learning courses is not available because the required bandwidth is not always available in the workplace or in regions where employees reside. This problem is illustrated by the comments of Gérôme, who says: " The bandwidth is insufficient. It takes an eternity to download an e-mail, forget videos and other sophisticated things. It would be difficult to administer training of this style with the system such as it operates at present. By the time a course would be online, the employees would have left home »(G:181-186). In addition, some SMEs do not have a training room equipped with the necessary equipment for this type of training, and some employees do not have a computer at home.

Another barrier mentioned by the majority of SMEs is the level of knowledge of employees towards computers. There are several employees whose level of knowledge is not sufficient or still, they have no interest in computers.

1 Nota: In Table 3, a "strong” use means that the business regularly uses e-learning to train its employees. An "average” use means that the business has developed at least two courses in e-learning format and that the production employees must take these courses. A "weak" use means that only few employees use it in the business and a "non-existent" use means that the business does not use e-learning to train its employees and that they do not use it to develop their knowledge.
The comments of Jules illustrate the problem « There are some employees who are fascinated by computers and there are others who don't want to touch them ...Is that the medium that is most suitable for these people to learn » (J:652-654). The motivation and discipline required to take a course online were also mentioned.

The lack of knowledge about the courses available is another barrier highlighted. It is not known what courses are offered, where they can be found, what their level of interaction is, what the possibilities of mentoring are, what the possibilities for the evaluation are and what level of security is necessary in order to avoid problems and ensure that it is the right person that participates in the course. Hector gives us an example of the lack of knowledge about what is available, he says: "there's no directory, or if there is one, I am not aware of it " (H:145-146).

The barriers cited by SMEs in the use of e-Learning are illustrated in Table 4. These barriers, as shown in Table 5, can be grouped into broad categories, namely: lack of access to computers or the Internet, the lack of training and support both for SMEs and for the employees, lack of knowledge on the courses and content relevant to the needs of SMEs including false expectations of SMEs as to what e-Learning can and cannot do, the level of interaction, the cost of purchases or development and the learner himself. The barriers faced by SMEs are similar to those found in the review of the literature.

TABLE IV.

\section{ILLUSTRATIONS OF THE BARRIERS ENCOUNTERED BY SMES}

- « The necessary bandwidth is not available in all regions. »Gérôme (G:264-267)

- «It lacks the facilities for such courses. [...]They were conditioned to receive training in a certain way, with a teacher. It will be difficult to change this. » Arthur (A:509-513:613-617)

- "Employees do not have all the necessary knowledge. " Ivan (I:822-830)

- «First we would have to know what is available. » Hector $(\mathrm{H}: 140$ 142)

- «It is difficult to find courses relevant to what you need and it takes time. » Bert (B:719-726)

- «The cost and time for development at the Internal are high. » Edna (E:419-423)

TABLE V.

BARRIERS TO THE USE OF E-LEARNING ACCORDING TO SMES

\begin{tabular}{|c|c|c|c|c|c|c|c|c|c|c|c|c|c|c|c|c|}
\hline \multirow[t]{2}{*}{ BARRIERS } & \multicolumn{16}{|c|}{ SME } \\
\hline & \multicolumn{4}{|c|}{$\begin{array}{l}\text { Profile I } \\
\text { STRONG }\end{array}$} & \multicolumn{4}{|c|}{$\begin{array}{l}\text { Profile II } \\
\text { AVERAGE }\end{array}$} & \multicolumn{4}{|c|}{$\begin{array}{l}\text { Profile III } \\
\text { WEAK }\end{array}$} & \multicolumn{4}{|c|}{$\begin{array}{c}\text { Profile IV } \\
\text { NON-EXISTENT }\end{array}$} \\
\hline \multirow[t]{2}{*}{ No. of employees } & \multicolumn{4}{|c|}{300 to 485} & \multicolumn{4}{|c|}{60 to 280} & \multicolumn{4}{|c|}{150 to 350} & \multicolumn{4}{|c|}{75 to 400} \\
\hline & C & D & $\mathrm{K}$ & $\mathrm{L}$ & B & E & $\mathrm{M}$ & $\mathrm{O}$ & A & $\mathrm{F}$ & $\mathrm{I}$ & $\mathrm{J}$ & G & $\mathrm{H}$ & $\mathrm{N}$ & $\mathrm{P}$ \\
\hline Accessibility & & $\mathrm{x}$ & & & $\mathrm{x}$ & & & & & & $\mathrm{x}$ & $\mathrm{x}$ & $\mathrm{x}$ & & & $\mathrm{x}$ \\
\hline Training and support & & & & & $\mathrm{x}$ & & & $\mathrm{x}$ & $\mathrm{x}$ & $\mathrm{x}$ & $\mathrm{x}$ & & $\mathrm{x}$ & & & \\
\hline Course and content & & & & & $\mathrm{x}$ & & $\mathrm{x}$ & & & & $\mathrm{x}$ & & $\mathrm{x}$ & $\mathrm{x}$ & $\mathrm{x}$ & $\mathrm{x}$ \\
\hline Interaction & & $\mathrm{x}$ & $\mathrm{x}$ & & & & & & & & $\mathrm{x}$ & & & $\mathrm{x}$ & & $\mathrm{x}$ \\
\hline Learners & $\mathrm{x}$ & & & $\mathrm{x}$ & $\mathrm{x}$ & & $\mathrm{x}$ & & & $\mathrm{x}$ & & $\mathrm{x}$ & & & & \\
\hline Costs & $\mathrm{x}$ & $\mathrm{x}$ & & $\mathrm{x}$ & $\mathrm{x}$ & $\mathrm{x}$ & & $\mathrm{x}$ & & $\mathrm{x}$ & & $\mathrm{x}$ & & & & \\
\hline
\end{tabular}


Therefore, in order for e-Learning to be a viable and feasible solution for all SMEs, we must eliminate, or at least alleviate some of these barriers. Activities to promote e-Learning, at all levels of the organization, have to be undertaken. The different approaches presented below to make a successful transition from traditional training to e-Learning are a start in that direction.

\section{B. Successful approaches for transition}

Ref. [1] considers that in the knowledge-based economies, the investment of a company in the training and update of the employees' skills are some of the key elements of growth. According to this organization, SMEs need to exploit the e-Learning to address their training needs in order to ensure their growth and survival. Ref. [42] and Ref. [43] mention more or less the same thing, and for the latter, e-Learning has to be part of the development of businesses in order to ensure their sustainability.

However, according to Ref. [37] and Ref. [38], if we want businesses to use e-Learning, barriers in using eLearning need to be removed or at least reduced. In addition, a culture more favourable to e-Learning, in addition to the benefits associated with it, encourages companies to use e-Learning [19]. Therefore, the approaches to incite SMEs to use e-Learning must include both actions to develop a culture more conducive to e-Learning and actions to remove or reduce barriers in using e-Learning.

According to Ref. [44], if companies want to position themselves so that they can compete on a global scale, they will need better skilled employees and in order to achieve this, they will need to embark on a culture change towards training. Moreover, the culture change must be transmitted and adopted by all stakeholders, i.e. by SMEs, the various players in economic development and society in general.

The development of a culture of learning and eLearning passes, among other things, by valuing learning and having a better understanding of the e-Learning [1; 24; 45]. The comment issued by Denise illustrates indeed the need to develop a culture of learning and enhance learning. She says: «We must develop a learning culture, in society in general, because without education or training businesses cannot survive. " (D:985-999) For its part, the comment issued by Ivan illustrates the need to learn more about e-Learning. He says: "There must be information sessions. People should be made aware of what is e-Learning. They should be presented a demo of what the e-Learning can do ». For its part, Jules says: "It is important that SMEs see practical examples of e-Learning, things that are already used by another company if you want them to invest or move in that direction. The best way to educate a group is to present the success of customers or other SMEs and to recommend them to verify this with them. [...] It is also necessary to develop success stories. » (J: 1546-1551:1557-1565:1582)

We need champions of e-Learning for the promotion and awareness of e-Learning in companies. This promotion and awareness can be done by internal champions of e-Learning $[14 ; 45 ; 46]$, as well as by external champions [1; 47; 48]. However, champions must have credibility and knowledge of e-Learning. The comment issued by Bert clearly illustrates the need for external champions of
e-Learning. He says: "Developing courses in-house is expensive and it takes a lot of time. We need a champion to lead the case. " (B:576:581-584) For its part, Edna illustrates the need for external champions of e-Learning. She says: "I think it should be someone, like economic development agencies, to tell SMEs about what is available. " (E:613-615) Monique’s comment also illustrates the need for external champions. She says: "The information spreads quickly around here. If a person is satisfied with the e-Learning, it won't take long for everyone to know. You can use agencies or groups to circulate the information. [...] I think we should encourage suppliers to give seminars to show what they have as courses. They could provide examples of people or businesses that use their courses. [...] They could show the different possibilities of e-Learning for various industries. " M:423427:848-851:861-866)

It is critical for an organization to determine what the overall learning strategy of the company is. The SME has to determine exactly what it is trying to accomplish with e-Learning [49]. Learning strategies need to be well thought out, carefully implemented, and most importantly, they must satisfy the wider business needs and goals. The importance of getting learning strategies right is at the core of e-Learning approval by SMEs and employees $[42,50]$. The firm must see e-Learning as a tool rather than a panacea [49]. Karen illustrates indeed the need for a learning strategy. She says: "The general manager decided to include training needs in the annual business planning and in the development plan of the company. Upper management sees the importance of training and on-going training. [... ] We made the analysis according to the objectives. [... ] We have online courses, as our courses on forklift and health and safety, all our production employees have to follow and redo them occasionally in order to get certified or re-certified. [...]They go online and do the courses. [...] We also have practical evaluations » (K:103-108:117-119: 378-387: 610-614).

As previously mentioned, in addition to actions in developing a culture more conducive to e-Learning, actions should be undertaken to remove or reduce barriers in using e-Learning if we want to encourage SMEs to use eLearning. To this end, various actions including the upgrading of employees' skills in technology in general and the e-Learning, offering technical support, the development of a toolbox, and the increase in bandwidth in some regions must be undertaken.

Among the factors that discourage SMEs and employees from using the e-Learning, we find the lack of knowledge towards this one and of the technology [51]. The comment of Hector is an example, he says: "First, it is necessary that SMEs are equipped with people who can prepare the material for the e-Learning. The IT equipment and the applications have to work. [...]. People who do the promotion have to know what they are talking about. It will take trained people to promote e-Learning to other businesses. " (H:386-398:410-412) Thus, in order to ensure that learners do not drop out or refuse to use e-Learning, we must ensure that employees have the equipment, the software, the skills and the necessary knowledge needed to use the e-Learning [45; 51]. Ivan gives us an example of the necessity to train employees, he says: "Employees do not have all the necessary 
knowledge. We might have to train them before they can use computers and e-Learning. " (I:822-830) It is also necessary to provide basic courses to those who do not know how to use computers. Jules's comment goes in this direction, he says: "Some of our employees do not have the knowledge and skills necessary [...]. » (J:654-658)

One of the factors which also discourage businesses to use e-Learning is the lack of support available. Thus, in order to ensure that SMEs and learners do not drop out or refuse to use the e-Learning, they must be given the necessary support to use the e-Learning [37; 38; 51; 52]. To this effect Ivan said: «It will take some support. There are some people who do not know how to download and install the necessary software. " (I: 886-901) He adds: «Universities or another organization should make resources available by e-mail or telephone, to provide a consulting service for SMEs. They could also leave a phone number that people could call, say between 4:00 pm and 6:00 pm, if they have questions. The questions would be answered by students, this would be part of their training and this would be an improvement for the business community. This would be a way to get people interested. » (I:1086-1098) For its part, Denise says : " It is necessary to speak the language of SMEs and employees. » (D:1020)

Although, according to Ref. [52] and Ref. [53], there are currently a large number of courses on the Internet and, even for SMEs, the lack of information about what is available on the Internet is one of the barriers identified in the use of e-Learning; barriers identified by both authors and SMEs themselves. To overcome this barrier, some researchers [53; 54; 55] suggested using tools to explore the availability of e-Learning, and thus better understand what is available on the Internet. For its part, Ref. [45] suggests to create and distribute tools to help companies use e-Learning. The comment of Gérôme illustrates well this need of a toolbox, he says: « The most interesting way would be to bring me a catalogue and to tell me what is available as training [...]." (Gérôme $\mathrm{G}: 595-597)$ Edna also expresses the need for a toolbox for SMEs or access to different resources. She says: "I think if the economic development agencies have libraries of courses pertinent to SMEs to train their employees, SMEs would see e-Learning as a very effective way to provide training. I think that it is necessary to develop inventories of existing courses or to give access to portals such as "Soft Skill" where there is a library that contains hundreds of useful courses to SMEs to train their employees. » (Edna E: 615-625 :627-643)

Finally, initiatives should be undertaken in order to increase bandwidth in the regions because this barrier reduces the ability of companies and employees to download training courses, in e-Learning format, depending on where they are. Ivan's comment goes in this direction. He says: " The Internet is the Internet. There are places where it is not fast [...] We need more bandwidth. " (I:886-898) Gérôme also mentions the need for more bandwidth, he says: " the speed of the line has to be greater (bandwidth), we should have a better network. " (G:268-270) For its part, Jules says: «Some employees may not have access to the Internet at home. » (J:10551064)
Even though communication is not as such a barrier to the use of e-Learning, it seems that the communication between SMEs and economic development agencies is not what it should be. Indeed, SMEs are under the impression that the agencies do not know their needs and that the programs they offer are not fitted to their needs. These problems are not directly related to e-Learning, but would have an impact on how SMEs can fulfill their needs. They could possibly be mitigated through various outreach initiatives emanating from the economic development agencies via an action plan.

\section{CONCLUSION}

There currently exist strong incentives, whether technological, economical, productivity or prosperity, for the SMEs to use technologies in everything that is related to training. In fact, the recent technological advances, along with a reduction of their costs allow them to reconsider training more easily and the method of offering this training.

An increasing number of SMEs in Atlantic Canada are aware of e-Learning and use it to train their employees. During this study, three quarters of the SMEs participating in the study use e-Learning, to various degrees, to train their employees. However, they face many barriers when they want to use e-Learning and these barriers are the same as those which larger organizations are facing, namely: the lack of access to computers or the Internet, the lack of training and support for both SMEs and employees, the lack of knowledge on the courses and content relevant to the needs of SMEs including false expectations of SMEs as to what e-Learning can and cannot do, the level of interaction, the cost of purchases or development and the learner himself. The culture toward learning and e-Learning is also a barrier.

A number of pre-requisites could constitute the core of an action plan to address these barriers and ensure that the transition from traditional training to e-Learning is a success and further enable e-Learning in SMEs. The first pre-requisite is the need to develop an e-Learning culture within the organization, where managers and employees are truly motivated and committed to using e-Learning because they believe it is essential to their individual development and their organisation's development. This implies greater awareness and promotion of e-Learning's value through the dissemination of knowledge among SMEs as to the nature, possibilities and advantages of eLearning for workplace training, and as to the supply and appropriateness of e-Learning services and products available. A second pre-requisite is the need to lower the present barriers to the efficient and effective use of eLearning by SMEs. This implies that employees possess the computer knowledge and skills required to use eLearning effectively, and that they be provided with computers and e-Learning software that are user-friendly and appropriate to the task at hand. This also implies better management and technical support of employees with regard to e-Learning, support which was found lacking in a number of SMEs. Champions must also be identified, inside and outside of SMEs, to promote e-Learning. Last but not the least, learning strategies have to be developed to satisfy business needs and goals.

Governments, economic development agencies, universities and society in general also have a role to play in 
this transition from traditional training to e-Learning, which is to develop a culture more conducive to training and e-Learning as well as to facilitate access to eLearning in order to ensure the growth and survival of SMEs.

\section{REFERENCES}

[1] OCDE. (2002). La formation des dirigeants des PME. Paris: Éditions de l'OCDE.

[2] APECA. (1998). État de la petite entreprise et de l'entrepreneurship dans la région de l'Atlantique 1998. APECA. Direction générale des politiques et des programmes.

[3] APECA. (2005). État de la petite entreprise et de l'entrepreneurship dans la région de l'Atlantique 2005. Moncton: Direction générale des politiques et des programmes.

[4] Brady, A. (1995). "Small is as small does", Journal of Business Strategy, Vol. 16, No. 2, pp. 44-52. doi:10.1108/eb039690

[5] Mittelstaedt, J.D., Harben, G.N. and Ward, W.A. (2003) "How small is too small? Firm size as a barrier to exporting from the United States", Journal of Small Business Management, Vol. 41, No. 1, pp. 68-84. doi:10.1111/1540-627X.00067

[6] Beamish, N., Armistead, C., Watkinson, M. and Armfield, G. (2002). "The deployment of e-learning in UK/European corporate organisations", European Business Journal, Vol 14, No.3, pp 105115.

[7] Misko, J., Choi, J., Hong, S.Y. and Lee, I.S. (2004), E-learning in Australia and Korea: Learning from practice, Seoul: Korea Research Institute for Vocational Education \& Training.

[8] Pailing, M. (2002) "E-Learning: Is it really the best thing since sliced bread?", Industrial and Commercial Training, Vol. 34, No. 4, pp. 151-155. doi:10.1108/00197850210429138

[9] Servage, L. (2005) "Strategizing for workplace e-Learning: Some critical considerations", Journal of Workplace Learning, Vol. 17, No. 5/6, pp. 304-317. doi:10.1108/13665620510606733

[10] Abram, S. (2003) "A primer on e-Learning: ... the framework, the market, the players", KM World, Vol 12, No. 2, p. 10.

[11] Welsh, E., Wanberg, C., Brown, K. and Simmering, M. (2003), "E-learning: Emerging uses, empirical results and future directions", International Journal of Training and Development, Vol 7, No. 4, pp 245-258. doi:10.1046/j.1360-3736.2003.00184.x

[12] ASTD. (2001). "A Vision of E-Learning for America's Workforce : Report of the Commission on Technology and Adult Learning". American Society of Training Directors. Policy and Public Leadership. Alexandria, [online], http://www.astd.org.

[13] Conference Board of Canada. (2001) E-Learning for the workplace: Creating Canada's life long learners, [online], http://www.conferenceboard.ca/elearning/Downloads/CBoC_SFP/ e-Learning_for_the_workplace.pdf

[14] Terry, L. (2000) "Get Smart Online", Upside, Vol. 12, No. 5, pp. 162-164.

[15] Gil, P. (2000) E-formation : NTIC et reengineering de la formation professionnelle. Paris: Dunod.

[16] IDC (2004) 2004 Corporate Education Taxonomy and Research Guide, [online], http://www.mindbranch.com/listing/product/R104-15161.html mars 2004

[17] Piccoli, G., Ahmad, R. and Ives, B. (2001) "Web-Based Virtual Learning Environments: A Research Framework and a Preliminary Assesment of Effectiveness in Basic IT Skills Training", MIS Quarterly, Vol. 25, No. 4, pp 401-426. doi:10.2307/3250989

[18] Bolan, S. (2001). "Canada behind in e-learning", Computing Canada, Vol 27, No. 9, p 4.

[19] Schweizer, H. (2004). "E-learning in business", Journal of Management Education, Vol 28, No. 6, pp 674-692. doi:10.1177/1052562903252658

[20] Economist Intelligence Unit. (2004). Europe company: Making the most of e-learning. NewYork, NY: EIU ViewsWire.

[21] Kenyon, H. S. (2002). "Learning online from the front line", Signal, Vol 56, No. 6, pp 49-51.

[22] Melymuka, K. (2002). "Executive education on a shoestring", Computerworld, Vol 36, No. 11, pp 24-25.
[23] Noble, D.F. (2002). Digital diploma mills: The automation of higher education. Toronto: Between the Lines.

[24] Nonprofit World (2002). "Reach out and train someone: The many faces of distance learning", Nonprofit World, Vol 20, no. 2, pp 2429.

[25] Rayfield, R. and Imel, L. (2002). "Making interactive video distance learning work", Principal Leadership, Vol 2, No. 4, pp 5661.

[26] Sanderson, P.E. (2002). "E-learning strategies for delivering knowledge in the digital age", Internet and Higher Education, Vol 5, No. 2, pp 185-188. doi:10.1016/S1096-7516(02)00082-9

[27] Tiene, D. (2002). "Digital multimedia \& distance education: Can they effectively be combined? ", T.H.E. Journal, Vol 29, No. 9, pp $18-25$.

[28] Moore, K.B. (2002). "Professional development through distance learning", Scholastic Early Childhood Today, Vol 16, No. 6, pp 6-

[29] Perez, S. and Foshay, R. (2002). "Adding up the distance: Can developmental studies work in a distance learning environment? ", T.H.E. Journal, Vol 29, No. 8, pp 19-24.

[30] Serwatka, J.A. (2002). "Improving student performance in distance learning courses", T.H.E. Journal, Vol 29, No. 9, pp 46-51.

[31] Spaulding, S. (2002). "Distance education, broadcast media, virtual reality, and cyberspace: Is the future passing us by? ", Comparative Education Review, No 46, Vol. 3, pp 119-130. doi:10.1086/324048

[32] Fulton, L. (1998). "Learning in a digital age: Insights into the issues", T.H.E. Journal, Vol 25, No. 7, pp 7-10.

[33] Cutshall, S. (2002). "Going the Distance: When Online Learning Works", Techniques, Vol 77, No. 5, pp 22-23.

[34] Phillips, V. (1998). "Virtual classrooms, real education", Nation's Business, Vol 86, No. 5, pp 41-45.

[35] Stevenson, N. (2000). Distance learning online for dummies. New York, NY: Hungry Minds Inc.

[36] Brandao, C. (2002). "Teaching online: Harnessing technology's power at Florida Virtual school", T.H.E. Journal, Vol 29, No. 10, pp 37- 42

[37] Industrie Canada (2001). L'évolution de l'apprentissage en ligne dans les collèges et les universités. [online], http://www.rescol.ca/mlg/sites/acol-ccael

[38] Web-Based Education Commission. (2000). The Power of the Internet for learning: Moving from promise to practice. Washington, DC: Government Printing Office.

[39] Yin, R.K. (1994), Case study research: Design and methods, $2^{\text {nd }}$ Edition, Thousand Oaks, California: Sage Publications.

[40] Wolff, J.A. and Pett, T.L. (2000), "Internationalization of small firms: An examination of export competitive patterns, firm size, and export performance", Journal of Small Business Management, Vol 38, No. 2, pp 34-47.

[41] Miles, M.B. and Huberman, A.M. (1994), Qualitative Data Analysis: An Expanded Sourcebook, $2^{\text {nd }}$ Edition, Thousand Oaks, California: Sage Publications.

[42] Berris, J. (2006). "A job like mine", E.learning Age, October 26, p 26.

[43] Filipczak, B. (1994). "The training manager in the '90s", Training, Vol 31, No. 6, pp 31-35.

[44] Middleton, C. (2003). "The rate of learning must be greater than the rate of change", Industrial and Commercial Training, Vol 35, No. 6/7, pp 306-308. doi:10.1108/00197850310508689

[45] Tanquist, S. (2001). "Marathon e-learning", $T+D$, Vol. 55, No. 8, pp 22-24.

[46] Clawson, T. (2004). "Teach the boss", Human Resources, Vol 12, pp 38-40.

[47] Manufacturiers et exportateurs du Québec. (2003). La formation par les TIC ou e-learning: le pourquoi et le comment: guide d'aide à la décision en contexte manufacturier. Montréal: Manufacturiers et exportateurs du Québec.

[48] TechnoCompétences (2002). E-learning: guide pratique de l'apprentissage virtuel en enterprise. Montréal: TechnoCompétences.

[49] Lustig, D. (2002). "How to transition to e-Learning", Pharmaceutical Executive, Vol. 22, No. 11, pp 114 -116. 
[50] Sonntag, M. (1994). Développer et intégrer la formation en entreprise. Paris: Les Éditions Liaisons.

[51] Zielinski, D. (2000). "Can you keep learners online? ", Training, Vol 37, No. 3, pp 64-75.

[52] Roffe, I. (2004), "E-learning for SMEs: Competition and dimensions of perceived value", Journal of European Industrial Training, Vol 28, No. 5, pp 440-455. doi:10.1108/03090590410533116

[53] Harris, P. (2005). "Small businesses bask in training's spotlight", $T+D$, Vol 59, No. 2, pp 46-52.

[54] Charp, S. (2002). "Assisting educators on the use of technology", T.H.E. Journal, Vol 29, No. 11, pp 10-11.
[55] Pantaziz, C. (2002). "Maximizing e-learning to train the $21^{\text {st }}$ century workforce", Public Personnel Management, Vol 31, No. 1, pp 21-26.

\section{AUTHOR}

A. Roy (andree.roy@umoncton.ca) is with the Université de Moncton, Moncton, NB, Canada E1A 3E9.

Manuscript received May $1^{\text {st }}, 2010$. Published as resubmitted by the author May 22 ${ }^{\text {nd }}, 2010$. 